\author{
Stawomira Sadowska \\ Uniwersytet Gdański \\ s.sadowska@ug.edu.pl
}

\title{
Reformatorskie działania w edukacji wczesnoszkolnej uczniów z niepelnosprawnością - „druzgocące fakty dokonane” czy postęp?
}

\author{
Summary \\ Reforming actions in early childhood education of pupils with disabilities - \\ "devastating facts made" or progress?
}

Reforming actions after the political change in 1989 brought new interpretations of work to the first stage of education and changes in the existing qualifications of teachers working in grades I-III of special schools. The read standards of work from the field of documents from the Ministry of Education stand in opposition to the expanse of positions expressed by scientific circles, while the first ones imprint their explicit stigma on the teacher conceptualizations of work in the first educational stage. The concept of work in classes I-III, developed on the basis of special pedagogy, despite the fact that the reformed school did not question its basic assumptions, is no longer an axis of thought in working with pupils with disabilities.

Słowa kluczowe: edukacja wczesnoszkolna, metoda ośrodków pracy, kształcenie zintegrowane

Key words: early school education, work centers method, integrated education

\section{Wprowadzenie}

Artykuł dotyczy zmian na pierwszym etapie edukacyjnym, jakie wymuszono ciągiem reform strukturalnych i programowych po zmianie politycznej w 1989 roku, a dokładniej tych, które zainicjował w 1999 roku rząd Jerzego Buzka. Analizy rozpościerać się będą pomiędzy tradycją propozycji pracy z uczniami z niepełnosprawnością na I etapie edukacyjnym, wyrastającą z myśli i praktyki pedagogiki specjalnej, a kolejnymi odsłonami reformy oświatowej. Ważnym elementem analiz będzie domena praktyk szkolnych i nauczycielskich koncepcji kształcenia.

Wdrażanie reformy poprzedziło nakreślenie głównych obszarów zmian w styczniu 1998 roku przez Mirosława Handke - Ministra Edukacji Narodowej. Kilka miesięcy później MEN wydało broszurę Reforma systemu edukacji: projekt (1998), a nowe zasady systemu szkolnego określiła ustawa uchwalona przez Sejm 25 lipca 1998 r. (Dz. U. 1998, Nr 117, poz. 759). Ustawą z dnia 8 stycznia 1999 r. (Dz. U. 1999, Nr 12, poz. 96) przyjęto przepisy wprowadzające reformę ustroju szkolnego, których następstwem była reforma 
programowa. Jednolite Podstawy programowe i Standardy wymagań miały gwarantować, że uczniowie, choć uczeni według różnych programów i z różnych podręczników, posiądą ten sam zakres zasadniczej wiedzy i porównywalne umiejętności. Na I etapie edukacyjnym (klasy I-III) wprowadzono kształcenie zintegrowane, także w szkołach specjalnych.

Reformatorskie działania po 1989 roku przyniosły zmiany w zakresie obowiązujących kwalifikacji nauczycieli szkół specjalnych, w tym kwalifikacji nauczycieli pracujących na I etapie edukacyjnym. Pierwszą wykładnią było rozporządzenie Ministra Edukacji Narodowej i Sportu z 10 września 2002 r. w sprawie szczegółowych kwalifikacji wymaganych od nauczycieli (...) (Dz. U. 2002 Nr 155 poz. 1288). W świetle tego dokumentu przygotowanie w ramach pedagogiki specjalnej upoważniało jedynie do prowadzenia zajęć opiekuńczych, wychowawczych i rewalidacyjnych. Absolwent pedagogiki specjalnej mógł pełnić funkcję nauczyciela w przedszkolach specjalnych (por. Parys 2005: 184). Inaczej mówiąc, by pracować w klasach I-III, trzeba było mieć kwalifikacje zgodne z nauczanym rodzajem prowadzonych zajęć i przygotowanie z pedagogiki specjalnej. Kolejne rozporządzenie Ministra Edukacji Narodowej z 12 marca 2009 r. (Dz. U. 2009 nr 50 poz. 400; z kolejn. zm.: Dz. U. 2012 poz. 174; Dz. U. 2012 poz. 426; Dz. U. 2014 poz. 1084) utrzymało praktykę „,dwutorowych” kwalifikacji. Ostatni projekt rozporządzenia, zmieniającego wcześniejsze regulacje (http://legislacja.rcl.gov.pl/projekt/12295107) nie wnosi $\mathrm{w}$ tej sprawie istotnych zmian. Od lat pedagodzy specjalni zabierają głos w tej sprawie. Początkowo ich stanowisko spajał prof. dr hab. W. Dykcik. Dzisiaj opinie pedagogów specjalnych są formułowane w ramach Zespołu Pedagogiki Specjalnej przy Komitecie Nauk Pedagogicznych PAN, którym kieruje prof. dr hab. Marzenna Zaorska oraz w pracach Polskiego Towarzystwa Pedagogów Specjalnych, któremu przewodniczy prof. dr hab. Amadeusz Krause.

Dalsze analizy ukierunkowuje pytanie: Czy z perspektywy pedagogiki specjalnej zmiany wywołane ciągiem reformatorskich działań można nazwać postępem?

\section{W kręgu konceptu pracy uczniów z niepelnosprawnością na pierwszym etapie edukacyjnym przed 1999 rokiem}

Źródeł propozycji pracy z uczniami z niepełnosprawnością na pierwszym etapie edukacyjnym można upatrywać w stanowiskach przedstawicieli Nowego Wychowania w Europie i pragmatyzmu w Stanach Zjednoczonych, a zwłaszcza z odmiany nauczania całościowego. Przykładem jest metoda projektów W.H. Klipatricka czy metoda ośrodków zainteresowań O. Decroly'ego, stanowiąca pierwowzór naszego rodzimego rozwiązania opracowanego przez zespół nauczycieli pod kierunkiem Marii Grzegorzewskiej - metody ośrodków pracy. Wprowadzenie go do polskich podstawowych szkół specjalnych wiązało się z założeniem, że pracę w szkole specjalnej należy oprzeć na dostarczaniu układowi nerwowemu dziecka „specjalnego”, warunków sprzyjających przystosowaniu się do ciągle zmieniającego się środowiska zewnętrznego i wewnętrznego (Grzegorzewska 1968: 105). Kluczowe było poznawanie na drodze obserwacji, kojarzenia i ekspresji, czyli 
oparcie nauczania na szeroko rozumianej poznawczej i praktycznej aktywności dziecka (Kirejczykowa, Marek-Ruka, 1983: 48-53; Doroszewska 1981: 651-669; Tkaczyk 1997). Silnie akcentowana też była indywidualizacja pracy.

W metodzie ośrodków pracy nauczyciel miał być tym, który organizuje środowisko poznawcze, uwzględniając potrzeby dzieci, by maksymalnie mogły one uczestniczyć w poznawczo-emocjonalnej eksploracji terenu. Ucznia postrzegano jako badacza - postulowano między innymi zdobywanie wiadomości od osób pracujących $\mathrm{w}$ danym terenie drogą stawiania im pytań przez dzieci (por. Doroszewska 1981: 647-653). Wybitny praktyk, Helena Seniowowa, pisała o tym: „Pracę trzeba tak ułożyć, by przy zastosowaniu różnorodnych jej form i różnych środków dydaktycznych, przy wielkim bogactwie sposobów oddziaływania na całą gromadę i na indywidualne odchylenia poszczególnych dzieci - nie zagubić się w szczegółach, nie stracić z oczu całości działania, lecz stworzyć dziecku warunki zapewniające rozwój ogólny i opanowanie koniecznego zasobu wiadomości i umiejętności z uwzględnieniem oczywiście możliwości dziecka na danym stopniu jego rozwoju. (...) Możliwości i potrzeby rozwojowe dziecka powinny być w centrum naszej uwagi przy planowaniu pracy. (...) Plan pracy nie jest czymś niewzruszonym i rygorystycznie obowiązującym w naszej metodzie, która układając naszą pracę z dzieckiem w otoczeniu wciąż zmieniającej się rzeczywistości - umożliwia nam i poleca giętkość i zmienność ram planu pracy, jeśli życie taką potrzebę przyniesie” (za: J. Doroszewska 1981: 651-652).

Twórczo adaptowana do warunków polskich belgijska metoda ośrodków zainteresowań spotkała się z radykalną krytyką władz na początku lat 50 . XX wieku. Na tle socjalistycznego światopoglądu i praktyki oświatowej w Związku Radzieckim zarzucano metodzie to, iż nie daje ona dzieciom rzetelnej wiedzy o otaczającym świecie, gdyż tylko na jej podstawie może się kształtować naukowy pogląd na świat, będący podstawą światopoglądu socjalistycznego. Krytykowano kształcenie oparte na zainteresowaniach dzieci, bo stało to w sprzeczności z zakładanym wychowaniem ideowym. Podkreślano wartość nauczania przedmiotowego jako dającego usystematyzowaną wiedzę o otaczającym świecie (por. Kirejczyk 1981: 407). W rezultacie w 1951 roku Ministerstwo Oświaty zakazało stosowania tej metody w szkołach specjalnych. Środowisko pedagogów specjalnych występowało w jej obronie. M. Grzegorzewska podkreślała wartości rewalidacyjne metod pracy w świetle nauki Pawłowa (Grzegorzewska 1955). Rok później ministerstwo wycofało zakaz. Efektem krytyki stała się jednak rezygnacja z nauczania metodą ośrodków pracy we wszystkich klasach szkoły podstawowej specjalnej.

Zredukowanie w latach 50. XX wieku propozycji pracy metodą ośrodków pracy do początkowego etapu kształcenia oraz ciąg reformatorskich posunięć ministerstwa przed 1999 rokiem prowadził do różnych prób periodyzacji rozwiązań kształcenia w szkołach specjalnych. Proponowano na przykład, by nauczanie w ośmioletnich szkołach specjalnych obejmowało trzy etapy: nauczanie całościowe (klasy I-IV), nauczanie kompleksowe (klasy V-VI), nauczanie przedmiotowe (klasy VII-VIII) (por. Błażejewska 1983). Propozycją przejścia od nauczania całościowego do nauczania przedmiotowego w projekcie 10-letniej szkoły (którą planowano tworzyć) było nauczanie skorelowane (por. Pańczyk 
1981). Różnice rozwiązań na poszczególnych etapach edukacyjnych opisywane były w perspektywie doboru treści, sposobu poznawania rzeczywistości, układu treści i organizacji procesu nauczania-uczenia się (por. tabela 1), co było znacznym uproszczeniem $\mathrm{w}$ odniesieniu do pierwowzoru rozwiązania pracy z uczniami niepełnosprawnymi.

Tabela 1. Scalanie zewnętrzne jako kluczowy element opisu etapów nauczania w szkole specjalnej w drugiej połowie XX wieku

\begin{tabular}{|c|c|c|c|}
\hline & $\begin{array}{l}\text { Nauczanie całościowe } \\
\text { (klasy I-IV) }\end{array}$ & $\begin{array}{c}\text { Nauczanie } \\
\text { kompleksowe/ } \\
\text { skorelowane } \\
\text { (klasy V-VI) }\end{array}$ & $\begin{array}{c}\text { Nauczanie } \\
\text { przedmiotowe } \\
\text { (klasy VII-VIII) }\end{array}$ \\
\hline $\begin{array}{l}\text { Dobór treści } \\
\text { poznawczych }\end{array}$ & $\begin{array}{l}\text { Tematyka dotycząca } \\
\text { najbliższego środowiska } \\
\text { rodzinnego i szkolnego } \\
\text { oraz otaczającej przyrody }\end{array}$ & $\begin{array}{l}\text { Tematyka dotycząca } \\
\text { całego kraju }\end{array}$ & $\begin{array}{l}\text { Tematyka dotycząca } \\
\text { całego świata }\end{array}$ \\
\hline \begin{tabular}{|l|} 
Sposób \\
poznawania \\
rzeczywistości
\end{tabular} & $\begin{array}{l}\text { Dominuje forma } \\
\text { bezpośredniego poznania } \\
\text { otaczającego świata. } \\
\text { Środkami dydaktycznymi } \\
\text { są przede wszystkim } \\
\text { naturalne okazy } \\
\text { w naturalnych albo } \\
\text { sztucznych warunkach. }\end{array}$ & $\begin{array}{l}\text { Stopniowe odchodzenie } \\
\text { od konkretu. } \\
\text { Stosuje się zarówno } \\
\text { poznawaie bezpośrednie } \\
\text { i pośrednie. }\end{array}$ & $\begin{array}{l}\text { Dominuje poznawanie } \\
\text { pośrednie. }\end{array}$ \\
\hline Układ treści & $\begin{array}{l}\text { Pełna integracja } \\
\text { i koncentracja treści } \\
\text { poznawczych }\end{array}$ & $\begin{array}{l}\text { Częściowa integracja } \\
\text { treści, które } \\
\text { grupują się wokół } \\
\text { zjawisk środowiska } \\
\text { geograficznego }\end{array}$ & $\begin{array}{l}\text { Coraz mniejsza } \\
\text { możliwość integracji } \\
\text { treści ze względu na } \\
\text { treści specjalistyczne, } \\
\text { które obejmują różne } \\
\text { przedmioty }\end{array}$ \\
\hline $\begin{array}{l}\text { Organizacja } \\
\text { procesu } \\
\text { nauczania - } \\
\text { uczenia się }\end{array}$ & $\begin{array}{l}\text { Wszystkie lekcje danego } \\
\text { dnia tworzą całość } \\
\text { i stanowią jednostkę } \\
\text { metodyczną tzw. ośrodek } \\
\text { dnia. }\end{array}$ & $\begin{array}{l}\text { W danym dniu (lub } \\
\text { dniach) różne lekcje } \\
\text { o zbliżonej tematyce } \\
\text { są realizowane } \\
\text { wspólnie i stanowią } \\
\text { samodzielną jednostkę } \\
\text { dydaktyczną, czyli całość } \\
\text { treściowo-organizacyjną, } \\
\text { inne lekcje są } \\
\text { realizowane oddzielnie, } \\
\text { poza kompleksem. }\end{array}$ & $\begin{array}{l}\text { Kompleksy } \\
\text { treściowo-organizacyjne } \\
\text { są zastępowane tylko } \\
\text { treściowymi, czyli } \\
\text { korelacją między } \\
\text { różnymi przedmiotami. }\end{array}$ \\
\hline
\end{tabular}

Źródło: opracowanie na podstawie E. Pasternak (1984), Materiały z metodyki kształcenia upośledzonych umystowo w stopniu lekkim w szkole specjalnej. UMCS, Lublin.

Propozycje etapów kształcenia z drugiej połowy ubiegłego wieku oraz towarzyszące im wyjaśnienia, których wyraźną egzemplifikacją jest zestawienie w tabeli 1, w pewien sposób przypominają te, jakie przenikały rynek publikacyjny w związku z zamysłem re- 
formatorskim z 1999 roku wprowadzenia w szkole podstawowej kształcenia zintegrowanego w klasach I-III, bloków przedmiotowych i ścieżek edukacyjnych w klasach IV-VI, zaś na etapie gimnazjum nauczania przedmiotowego. Przyjęło się wyjaśnianie, że skoro świat istnieje jako całość, to aby nauczyć dzieci żyć i działać w takim świecie, konieczne jest scalanie treści, materiału nauczania i wychowania w jednostki tematyczne, które na wyższych etapach dydaktycznych ustępują miejsca nauczaniu przedmiotowemu. Można zatem powiedzieć, że wzory pracy metodą ośrodków pracy w wielu opracowaniach metodycznych z okresu przed wprowadzeniem reformy w 1999 roku koncentrowały się na formalnych elementach metody i nierzadko daleka była od idei, jaka przenikała myśl pedagogiczną w początkowym okresie pracy metodą ośrodków pracy. Odejście od pierwotnego znaczenia metody ośrodków pracy, charakterystyczne zwłaszcza dla opracowań poradnikowych, potęgować mogły projekty badawcze zorientowane na formalne elementy zajęć. W deklaracjach ich realizatorów (Muszyńska, Pańczyk 1991; Tkaczyk 1999; 2003) dotyczyły tego, czy nauczyciele realizują teoretyczne założenia metody, co sprowadzane było do rozpoznawania, czy konstrukcja zajęć w dziennym ośrodku pracy jest zachowana, czy przeprowadzane są wszystkie etapy metody (zajęcia wstępne, obserwacja, przeróbka umysłowa, ekspresja, zajęcia końcowe), ile czasu trwają poszczególne elementy w ramach etapów oraz jakie ćwiczenia są stosowane.

W przestrzeni publikacyjnej z lat 80. i 90. XX wieku, zdominowanej wzorcami pracy korespondującymi z propozycją przedstawioną w tabeli 1, brakowało głosów krytycznych tych rozwiązań. Jeszcze raz odwołam się tu do stanowiska H. Seniowowej i jej pouczającej myśli, wypowiedzianej po wycofaniu w latach 50. metody ośrodków pracy ze szkół specjalnych. Dostrzegając niebezpieczeństwa, jakie niosły propozycje nowych rozwiązań pracy w szkołach specjalnych, napisała: „Bardzo poważnie może utrudnić pracę metodą ośrodków identyfikowanie jej z metodą korelacji nauczania. Zjawisko to występuje, niestety, dosyć często $\mathrm{z}$ winy pozornego podobieństwa między metodą ośrodków pracy a metodą korelacji. Podobieństwo dotyczy tylko wycinka pracy dydaktycznej, a mianowicie - «obrazu» dnia nauczania, i to zewnętrznego obrazu: w metodzie ośrodków obserwujemy ujęcie procesu nauczania w ośrodek pracy dnia, zaś w metodzie korelacji - powiązanie tematyczne różnych przedmiotów nauczania występujących oddzielnie w danym dniu. (...) Zasada metody ośrodków pracy wyraża się nie tylko w układzie materiału nauczania (ośrodki). Istota różnicy leży głębiej: dotyczy ona roli dziecka w procesie nauczania oraz zgodności toku procesu nauczania z prawami czynności układu nerwowego, w zgodności toku procesu nauczania z prawami procesu poznawczego. (...) Bez działania dziecka w procesie obserwacji, w procesie rozumienia związków i zależności między zjawiskami, tworzenia sądów i uogólnień oraz w procesie stosowania teorii w praktyce, bez poznawania przez dziecko przedmiotów i zjawisk drogą przeżywania całych sytuacji i w odpowiednim dla danego obiektu czy zjawiska środowisku, w warunkach normalnych dla danych treści poznania, bez uzgodnienia toku procesu nauczania z prawami czynności układu nerwowego nie ma metody ośrodków pracy, pozostanie korelacja, może tylko trochę «ulepszona». Zjawisko nazywania takiej «ulepszonej korelacji» metodą ośrodków 
pracy ma, niestety, dość często (...) miejsce w praktyce szkół specjalnych. Ze zjawiskiem tym w klasach niższych trzeba walczyć, ponieważ kryje ono w sobie niebezpieczeństwo łatwizny, spłycenia rewalidacyjnej pracy szkoły specjalnej” (za: Doroszewska 1981: 652653). Postulat autorki może być aktualny również dziś.

\section{W kręgu konceptualizacji pracy na I etapie edukacyjnym po 1999 roku}

Wejście w życie reformy w 1999 roku jeszcze wyraźniej zerwało związek konceptualizacji pracy na I etapie edukacyjnym z pierwotnym konceptem pracy w pedagogice specjalnej. Jednak dyskusję nad decyzją MEN zdominowali pedagodzy, a nie pedagodzy specjalni. Kanoniczną linią rozważań związanych z reformą oświatową po 1989 roku, przyjętą w dyskursie naukowym pedagogiki specjalnej, były problemy integracji uczniów. Na mocy ustawy z dnia 7 września 1991 r. (Dz. U. 1991 Nr 95 poz. 425) nastąpiło „otwarcie" systemu oświaty dla uczniów z niepełnosprawnością. Problemy konceptualizacji pracy na I etapie edukacyjnym nie rodziły wśród pedagogów specjalnych takich polemik jak kwestie integracji w kształceniu. Propozycja kształcenia zintegrowanego jest zbieżna z konceptem pracy utrwalonym tradycją i dotychczasowym kształceniem nauczycieli pedagogów specjalnych.

Znaczącym dokumentem była tu podstawa programowa dla sześcioletnich szkół podstawowych i gimnazjów (Rozp. MEN z dnia 15 lutego 1999 r.; zał. nr 1), wspólna dla uczniów pełnosprawnych i z niepełnosprawnością, z wyjątkiem dzieci z niepełnosprawnością intelektualną w stopniu umiarkowanym, znacznym i głębokim. We wstępie do niej czytamy: „Nauczyciele (...) powinni współdziałać na rzecz tworzenia w świadomości uczniów zintegrowanego systemu wiedzy, umiejętności i postaw. Ma to szczególne zastosowanie w nauczaniu początkowym. Integracji wiedzy nauczanej w szkole na różnych etapach kształcenia służy wprowadzenie: 1) kształcenia zintegrowanego w klasach I-III szkoły podstawowej, 2) bloków przedmiotowych, 3) ścieżek edukacyjnych” (Dz. U. 1999 $\mathrm{Nr}$ 14. poz. 129; s. 585). Zapis ten pozwala uznać, że dla reformatorskiego zamysłu znaczący był koncept integracji wiedzy uczniów, a kształcenie zintegrowane postrzegano jako ważną drogę realizacji tego celu. Dalsza lektura tego dokumentu, jak i innych prób przedstawiania koncepcji idei zintegrowanej edukacji, wniosek ten jednak pozwala obalić. W efekcie tej lektury kształcenie zintegrowane można było odczytywać przede wszystkim jako koncept integracji treści nauczania, co interpretowano jako synchronizację czasową i przyczynowo-skutkową treści z różnych obszarów wiedzy. Takie odczytanie wzmacniała rezygnacja z ujęcia treści nauczania bez podziału na przedmiotu.

Próby przybliżenia nowego rozwiązania można odnieść do szkoleń nauczycieli, poradników metodycznych, które „obudowywały” reformatorski zamysł. W cyklu „Biblioteczka Reformy" ukazała się broszura Ministerstwo Edukacji Narodowej o reformie programowej: I etap edukacyjny: ksztatcenie zintegrowane (1999). W poradniku, który ukazał się w przededniu wejścia w życie reformy (Kowalik-Olubińska, Świątek 1999: 46-48), zalecenia dla nauczycieli klas początkowych sprowadzały się do następujących 
wskazań: scalać treści oraz materiał nauczania i wychowania; łączyć treści z różnych programów i przedmiotów w logicznie powiązane struktury; łącznie ujmować cele wychowania, nauczania i kształcenia; stosować różnorodne metody i formy (indywidualne, zespołowe); urozmaicać zadania; naprzemiennie stosować różne rodzaje aktywności u uczniów w odcinkach czasowych regulowanych możliwościami, potrzebami, rytmem biologicznym ucznia. Autorki poradnika wskazywały więc na integrację treści, celów, metod i form organizacyjnych. Podobnie przedstawiano to w innych poradnikach. Na stronach archiwalnych jednego $\mathrm{z}$ ważnych wydawnictw szkolnych propozycje reformatorskie określono następująco: „W klasach I-III szkoły podstawowej (...) obowiązuje kształcenie zintegrowane. Wiedza i umiejętności nauczane poprzednio na lekcjach języka polskiego, matematyki i środowiska są obecnie nauczane razem, bez oddzielania przedmiotów i metod nauczania" (http://nauczyciel.wsipnet.pl/serwisy/reforma/arch/ref181a.htm).

Ocena tych i innych dokumentów przez środowisko pedagogów jest druzgocąca. Wskazuje się nie tylko na mglistość reformatorskich intencji, ale i problem rozdziału teorii pedagogicznych od praktyki pracy na etapie edukacji wczesnoszkolnej. W pewien sposób ta przestrzeń jest zbieżna z przestrzenią krytyki wobec propozycji zmian w kształceniu specjalnym w drugiej połowie XX wieku. Na przykład w książce pod znaczącym tytułem: Sensy i bezsensy edukacji wczesnoszkolnej czytamy na ten temat: „Z pewnością dążenie do tego, by wiedza w umysłach uczniów miała charakter zintegrowany, a więc była spójna i systemowa, a przez to dynamiczna, elastyczna, dostępna jednostce w formie refleksji i działania w zróżnicowanych sytuacjach, jest godne wysiłku pedagogicznego. Jednak wiedza zintegrowana to zupełnie co innego niż asocjacje wokół wspólnego tematu. Nie ulega wątpliwości, że nie w tematach i w czasie ich trwania kryje się klucz do wiedzy zintegrowanej” (Klus-Stańska, Nowicka 2005: 182). Znaczące oceny zawarto w publikacji z projektu realizowanego pod kierownictwem merytorycznym i organizacyjnym Zakładu Teoretycznych Podstaw Edukacji WSE UAM (por. Sowińska, 2011). Interesujących analiz odsłaniających słabości polskiej edukacji wczesnoszkolnej dostarczają też autorzy tekstów zgromadzonych w książce (Anty)edukacja wczesnoszkolna (Klus-Stańska 2014), uwzględniający też przestrzeń zmian wprowadzonych kolejnymi regulacjami prawnymi.

Należy zauważyć, że ministerialne koncepcje kształcenia w klasach I - III były niekonsekwentne w zapisach podstawy programowej z dnia 23 grudnia 2008 r. Przyjęto tu, że kształcenie w klasach I-III przyjmuje nazwę ,edukacja wczesnoszkolna” (Dz. U. 2009 $\mathrm{Nr} 4$, poz. 17; zał. 2, s. 206), a treści nauczania podzielono na obszary korespondujące z przedmiotami nauczania na etapie drugim. G. Rura (2011: 46) tę zmianę ocenia następująco: „Nowa podstawa programowa nie jest dokumentem nowatorskim, ale zbiorem deklaratywnych frazesów i pozornych działań reformatorskich. Konstytuuje fikcję i sprzeczności (...). Wycofując się z kształcenia zintegrowanego, nie wskazuje innej równie korzystnej dla rozwoju dziecka - alternatywy". J. Bałachowicz (2009) podkreśla, że w rozwiązaniach z 2008 roku ponownie widać wiele sprzeczności, a w oficjalnych dokumentach na temat reformy, kierowanych do nauczycieli, nadal dominuje pasywno-instrumentalne rozumienie edukacji adresowanej do ucznia o przeciętnych możliwościach. 
Zwraca się uwagę na zadekretowanie możliwości kształcenia przedmiotowego w klasach młodszych, choć z zaleceniami korelacji treści, co w praktyce ma już miejsce. H. Sowińska (2011) w kontekście tych zmian pisze: „Wprowadzane ostatnio w oświacie zmiany nie wynikają z badania i rzetelnej analizy przyczyn niepowodzeń szkoły, są wprowadzane na mocy intuicyjnych przeświadczeń decydentów, przy jednoczesnej rezygnacji z tego, co było istotą koncepcji, na której opierała się reforma" (Sowińska 2011: 11).

W kolejnej zmianie podstawy programowej z 30 maja 2014 r. (Dz. U. 2014 poz. 803; zał. 2, s. 9) i z 7 czerwca 2016 r. (Dz. U. 2016 poz. 895; zał. 2, s. 9), utrzymany został zapis dla I etapu edukacyjnego (edukacja wczesnoszkolna) oraz podział treści nauczania na obszary edukacyjne korespondujące z przedmiotami nauczania na etapie drugim. Dla pełni obrazu odnotuję, że ustawodawca, informując o podziale podstawy programowej dla szkół podstawowych na dwa etapy kształcenia, wskazuje, że edukacja wczesnoszkolna jest „realizowana w formie kształcenia zintegrowanego” (Dz. U. 2009 $\mathrm{Nr}$ 4, poz. 17; zał. 2, s. 208; Dz. U. 2014 poz. 803; zał. 2, s. 10; Dz. U. 2016 poz. 895; zał. 2, s. 10). Najnowsza podstawa programowa z 14 lutego 2017 r. powiela ten zapis (Dz. U. 2017, poz. 356, s. 15).

Choć głosy pedagogów specjalnych nie dotyczyły w istocie nowej propozycji pracy na I etapie edukacyjnym, jednak ten etap nie był zupełnie poza ich uwagą. Oceny dotyczyły na przykład programów i materiałów dydaktycznych dla uczniów pełnosprawnych w zakresie wspomagania umiejętności nawiązywania i utrzymywania przez nie kontaktów $\mathrm{z}$ osobami niepełnosprawnymi. Taki cel zapisany był od wprowadzenia reformy w podstawie programowej w 1999 r. Analizy ujawniły zasadnicze rozbieżności między postulatami i oczekiwaniami wobec edukacji a zawartością szkolnych materiałów edukacyjnych. Obraz dzieci z niepełnosprawnością w tekstach szkolnych jest powierzchowny i uproszczony, kreuje się wizerunek osoby innej, zależnej od pełnosprawnych, niesamodzielnej i oczekującej pomocy (por. Sadowska 2002; 2005).

Uwaga pedagogów specjalnych skoncentrowana też była na nowych programach nauczania uczniów z niepełnosprawnością, które w zdecydowanej większości nie odpowiadały metodzie ośrodków pracy. Dyskusję wzbudzało uszeregowanie i hierarchia treści kształcenia. Zawarte w nich ogólnikowe procedury osiągania celów, propozycje tematyki integralnych ośrodków wielokierunkowej działalności ucznia czy przykładowe scenariusze zajęć stanowiły wątpliwe wsparcie dla nauczyciela, by nakreślone reformą kierunki realizować. Niektóre z tych zapisów przywołam: „Działania podejmowane przez nauczyciela wymagają niezwykle przemyślanego zestawu metod i form pracy oraz starannego doboru środków dydaktycznych”; „Szkoła jest miejscem aktywnego rozwiązywania różnorodnych problemów, czemu towarzyszy przyjemność, radość tworzenia, poczucie własnej wartości, świadomości swoich możliwości, wiara w siebie, smakowanie sukcesu, optymizm i zadziwienie pięknem świata" (za: Sadowska 2006: 168). Krytykowano brak wystarczającej troski MEN o kształcenie osób z niepełnosprawnością. Gdy nauczyciele nauczania początkowego na początku reformy mogli wybierać spośród 54 programów nauczania, to wykaz dla uczniów z niepełnosprawnością intelektualną w stopniu lekkim 
w klasach I-III obejmował jeszcze we wrześniu 2005 roku jedynie 4 programy (por. Sadowska 2006). W następnych latach sytuacja się istotnie nie poprawiła.

Regulacje ostatnich lat, związane z kształceniem uczniów z niepełnosprawnością, w istocie zniosły odpowiedzialność MEN w zakresie tworzenia programów edukacyjnych dla tej grupy uczniów. Pierwsze zmiany w tym zakresie nastąpiły wraz z wejściem w życie rozporządzenia MENiS z dnia 18 stycznia 2005 r. w sprawie warunków organizowania kształcenia, wychowania i opieki dla dzieci i młodzieży niepełnosprawnych (...) (Dz. U. $2005 \mathrm{Nr}$ 19, poz. 167). Nauczyciele zostali zobowiązani do dostosowania realizacji programów do potrzeb uczniów niepełnosprawnych i opracowania indywidualnych programów edukacyjno-terapeutycznych. Na mocy dwóch kolejnych rozporządzeń z 17 listopada 2010 r. (Dz. U. $2010 \mathrm{Nr} 228$, poz. 1489; Dz. U. $2010 \mathrm{Nr} 228$, poz. 1490) to zobowiązanie objęło wszystkich nauczycieli przedszkoli i szkół. W rozporządzeniu z dnia 24 lipca 2015 r. (Dz. U. 2015, poz. 1113) utrzymano ten zapis.

Dotychczasowa analiza pozwala zauważyć, że ciąg reformatorskich działań doprowadził $\mathrm{w}$ istocie do odrzucenia dorobku pedagogiki specjalnej w zakresie konceptu pracy z uczniami z niepełnosprawnością na I etapie szkoły podstawowej, a decyzja o takim kształcie rozwiązań podjęta została poza środowiskiem pedagogów specjalnych. Zmieniły się też wyraźnie wymagania w zakresie kwalifikacji nauczycieli tego etapu kształcenia. Aktualna rzeczywistość oświatowa i obecny system kształcenia pedagogów i nauczycieli są pretekstem do pełnego niepokoju odnoszenia się w przestrzeni publikacyjnej do wypełniania zadań profesji pedagoga specjalnego oraz zadań kształcenia uczniów z niepełnosprawnością, jakie stają przed nauczycielami, którzy nie mają przygotowania z pedagogiki specjalnej (por. Janiszewska-Nieścioruk, Sadowska 2016; Olszewski 2016).

\section{O przestrzeni konceptualizacji pracy przez nauczycieli}

Konceptualizacja I etapu edukacyjnego wyznaczona przez dokumenty MEN wpływa na myślenie i działanie nauczycieli. Już kilka lat po wprowadzenia reformy J. Bałachowicz (2003) donosiła, że kluczem nauczycielskiego myślenia o zintegrowanej edukacji jest rezygnacja z nauczania przedmiotowego na rzecz całościowego ujmowania treści, rezygnacja z dzwonków, dowolność w doborze treści kształcenia. Niemniej znaczące dla nauczycieli były kwestie planowania sytuacji edukacyjnych wywołujących różnorodne formy aktywności oraz ramy czasowe dla ich realizacji. Szeroko zakrojone badania nad stanem edukacji wczesnoszkolnej w Polsce po reformie oświatowej z 1999 roku, w które włączyło się w 2008 roku dwanaście ośrodków naukowych, odsłaniają podobne kwestie. Autorzy raportu piszą: „,nauczyciele nie znają i nie rozumieją istoty edukacji zintegrowanej, ich wiedza jest powierzchowna, o czym świadczy między innymi brak umiejętności przetransponowania ogólnie przyswojonych przez nich haseł na wartościowe, realizujące ogólne założenia koncepcji, rozwiązania realizacyjne - metodyczne i organizacyjne. Wiedza nauczycieli z tego zakresu ma charakter deklaratywny" (Sowińska i in. 2011: 560-561). Ten niepokojący obraz jest o tyle znaczący z perspektywy pedagogiki specjal- 
nej, że to nauczyciele szkół ogólnodostępnych wyznaczają współcześnie rzeczywistość edukacyjną nie tylko uczniom pełnosprawnym, ale coraz większej liczbie uczniów z niepełnosprawnością, pobierającym naukę poza szkołą specjalną.

Badawcze rozpoznania wśród nauczycieli szkół specjalnych są nieliczne. A. Piotrowska (2016) przeprowadziła badanie realizowane w strategii jakościowej wśród pięciu nauczycielek pracujących w szkołach specjalnych z północno-wschodniej Polski. Zastosowany wywiad skłaniał badane do podjęcia namysłu nad własnym doświadczeniem, co prowadziło do wyrażenia przez nie jak najszerszej gamy aspektów pracy zarysowującej się w świadomości. Trzy badane były w przedziale wiekowym 24-27 lat, dwie w przedziale wiekowym 48-60 lat. Reprezentowały więc dwa różne pokolenia - osoby, które ukończyły studia po 2008 roku, jak i te, które ukończyły studia przed 1999 rokiem. Analiza wypowiedzi nauczycielek nie pozwala wyznaczyć wspólnych ram konceptu, jaki buduje ich nauczycielskie działanie na pierwszym etapie edukacyjnym w szkole specjalnej. Nauczycielki ze starszej grupy wiekowej, których pierwszymi kwalifikacjami były te z zakresu pedagogiki specjalnej, nie wiązały terminu ,kształcenie zintegrowane” z etapem edukacji, na którym pracowały. Termin ten odnosiły do integracji pełno- i niepełnosprawnych. Znaczące jest też to, że wskazywały na metodę ośrodków pracy jako rozwiązanie, które stanowi ich praktykę. Walor tej metody widziały jednak w odwołaniu do kategorii, które silnie akcentowane były w czasie reform - łączenie treści. Własną pracę konceptualizowały częściej w odwołaniu do cech pedagoga specjalnego niż cech jego działania. Poznanie ucznia, indywidualizacja pracy, bycie przewodnikiem dla ucznia było wyraźnie uobecnione w koncepcie ich pracy. W wypowiedziach dwóch nauczycielek, które ukończyły studia po 2008 roku, wyraźnie obecne były przeświadczenia eksponowane w poradnikach dla nauczycieli, sprowadzające myślenie o kształceniu zintegrowanym do łączenia treści. Hasłom indywidualizacji, aktywności towarzyszy przekonanie, że dobry nauczyciel to ten, który dobrze przekazuje wiedzę.

Wszystkie przywołane badania wyraźnie potwierdzają wpływ dyskursu towarzyszącego reformom na kształt przekonań nauczycieli w zakresie konceptu pracy w klasach I-III. Przykład badań prowadzonych wśród nauczycieli szkół specjalnych wskazuje dodatkowo na różnice, jakie wyznaczają kwalifikacje nauczycieli i tryb ich uzyskiwania. Znamienne jest to, że nauczycielki, których pierwszymi kwalifikacjami były kwalifikacje z zakresu pedagogiki specjalnej, mówiły o swojej pracy, odwołując się do ram konceptualnych z pola pedagogiki specjalnej, w które wpisywały hasła reform. Wypowiedzi nauczycielek, których pierwszymi kwalifikacjami były kwalifikacje z edukacji wczesnoszkolnej (zdobyte, gdy reforma trwała już kilka lat), były bardziej zróżnicowane, choć tylko jedna $\mathrm{z}$ badanych nauczycielek, która ukończyła renomowaną uczelnię, w których prowadzący zajęcia są autorami znaczących publikacji z obszaru edukacji wczesnoszkolnej, krytycznie odnosiła się do powierzchownego scalania treści kształcenia i wyraźnie wykazywała najmniejszą obecność przeświadczeń eksponowanych w dokumentach MEN i w poradnikach dla nauczycieli. 


\section{Uwagi końcowe}

Objęte uwagą w tym tekście działania reformatorskie przypadają na czas urzędowania 19 ministrów. Konfrontacja ich z tradycją propozycji pracy z uczniami z niepełnosprawnością na I etapie edukacyjnym rozszerza to spojrzenie na kolejne rządy. Analiza prowadzi do wniosku, że ciąg reformatorskich działan doprowadził do zaprzepaszczenia dorobku pedagogiki specjalnej w zakresie konceptu pracy z uczniami z niepełnosprawnością na I etapie szkoły podstawowej. Szeroka mapa reform, ogłoszona przez rząd Beaty Szydło, nie zapowiada w tym zakresie zmian. Kształt rozwiązań pracy na tym etapie podejmowany jest poza środowiskiem pedagogów specjalnych.

Trudno oprzeć się wrażeniu, że dla reformatorów najistotniejsze są względy polityczne, które stają się główną motywacją do podejmowania działań związanych z reformowaniem. Z.A. Kłakówna (2014: 28), analizując kwestie reformatorskich posunięć od 1999 roku, zwraca uwagę, że praktyki rządzących zdają się wpisywać w powtarzający się rytm, który obejmuje trzy etapy: „Pierwszy dotyczy hierarchizowania problemów ważnych dla danego zagadnienia, skutkuje bagatelizowaniem i pomijaniem niektórych - zwłaszcza gdy naruszają ideologię założeń; drugi pozwala długo i bezkarnie ignorować niepokojące zjawiska i zdarzenia, a gdy przekształcą się one w druzgocące fakty dokonane, następuje etap trzeci, więc czas konstatacji, że pora grać larum. Z tym, że na ogół kto inny napędza cały proces, kto inny z okazji korzysta, a całkiem kto inny ponosi bezpośrednie koszty. Faza alarmu wyzwala z kolei, co zrozumiałe arcysamo przez się, pospieszne, doraźne działania naprawcze, z powodu których w niedługim czasie znów można się będzie solidnie spłakać".

Krytyczne głosy płynące $\mathrm{z}$ analiz pedagogicznych $\mathrm{w}$ istocie $\mathrm{w}$ niewielkim stopniu uruchamiają fazę alarmu u ekip rządzących. Niepokojący obraz szkoły, wyłaniający się z doniesień naukowych, jest instrumentalnie wykorzystywany przez strony w debacie publicznej - uczestnicy głównego dyskursu edukacyjnego, znosząc dysonans między „dobrym” a „złym” obrazem szkoły, łączą ze sobą, na użytek realizowanych zadań, trzy narracyjne ujęcia szkoły: deklaratywną wizję, systemowy wzór działania, konkretne realizacje tego wzorca. Rozmowy o edukacji, jakie toczą się dziś w głównym nurcie debaty publicznej o edukacji, prowadzone są w duchu kulturowej oczywistości. W ten sposób sprawiamy, że rozmowa o edukacji: ma zredukowany temat (utożsamiamy szkołę z instytucją usługową, z wszelkimi tego konsekwencjami); jest jednowymiarowa i bezkrytyczna (typowy schemat narracyjny traktujemy jako ponadczasowy i uniwersalny wzorzec myślenia o edukacji); jest prowadzona w stylu monologowym (uznajemy kulturowy schemat myślenia za bezwarunkowo ważny i nieufnie podchodzimy do poglądów ujawniających różnicę myślenia) (Kwaśnica 2014: 47-48).

Obezwładniający wpływ dyskursu, jaki przenika dokumenty ministerialne oraz wpływ „kulturowej oczywistości” jako archiwum tego dyskursu, stawia przed uczelniami wyzwanie realnego oddziaływania $\mathrm{w}$ procesie kształcenia nauczycieli na ich konceptualne schematy pracy. Nie wystarczy szkolenie zawodowe. Ważne jest gruntowne poznanie idei 
konceptu pracy. Wzorce pracy muszą podlegać interpretacji, w tym też krytycznej. Przed uczelniami stoi wyzwanie wywoływania realnego wpływu na myślenie nauczycieli. Niesie to nadzieję, że ton debaty publicznej, która dotyczy edukacji, będą nadawać nie tylko media, politycy, ale i ludzie kultury i nauki, nauczyciele.

\section{Literatura}

Bałachowicz J. (2003), Początkowe kształcenie zintegrowane - problemy teoretyczne i praktyczne. W: D. Klus-Stańska, M.J. Szymański, M.S. Szymański (red.), Renesans (?) nauczania całościowego, Współczesna dydaktyka wobec nauczania zintegrowanego, blokowego i przedmiotowego. Warszawa, Wydawnictwo Akademickie „Żak”.

Bałachowicz J. (2009), Ocena nowej podstawy programowej klas I-III w świetle podmiotowego modelu edukacji. „Problemy Wczesnej Edukacji” nr specjalny.

Błażejewska A. (1983), Nauczanie dzieci upośledzonych umysłowo w klasach V-VIII. W: H. Borzyszkowska (red.), Nauczanie dzieci upośledzonych umysłowo w klasach specjalnych: materiały pomocnicze dla nauczycieli. Warszawa, WSiP.

Doroszewska J. (1981), Pedagogika specjalna. T. 1, Podstawowe problemy teorii i praktyki. Wrocław, Zakład Narodowy im. Ossolińskich.

Grzegorzewska M. (1955), Uzasadnienie w świetle nauki Pawłowa wartości rewalidacyjnych metod pracy w szkole specjalnej. „Studia Pedagogiczne”, t. II.

Grzegorzewska M. (1964), Wybór pism. Warszawa, PWN.

Grzegorzewska M. (1968), Pedagogika specjalna: skrypt wykładów. Warszawa, PIPS.

Janiszewska-Nieścioruk Z., Sadowska S. (2016), Problemy zwiazane z probolońskim kształceniem pedagogów i nauczycieli w Polsce. „Niepełnosprawność. Dyskursy Pedagogiki Specjalnej”, 23.

Kirejczyk K. (1981), Metoda Decroly'ego, metoda ośrodków zainteresowań a metoda ośrodków pracy. W: K. Kirejczyk (red.), Upośledzenie umysłowe - Pedagogika. Warszawa, PWN.

Kirejczykowa S., Marek-Ruka M. (1983), Organizacja nauczania dzieci upośledzonych umysłowo w stopniu lekkim. W: H. Borzyszkowska (red.), Nauczanie dzieci upośledzonych umysłowo w klasach specjalnych: materiały pomocnicze dla nauczycieli. Warszawa, WSiP.

Klus-Stańska D. (red.) (2014), (Anty)edukacja wczesnoszkolna. Kraków, Oficyna Wydawnicza „Impuls".

Klus-Stańska D., Nowicka M. (2005), Sensy i bezsensy edukacji wczesnoszkolnej. Warszawa, WSiP.

Kłakówna Z.A. (2014), Jakoś i jakość. Subiektywna kronika wypadków przy reformowaniu szkoły (1989-2013). Kraków, UNIVERSITAS.

Kowalik-Olubińska M., W. Świętek (1999), Uczymy inaczej. Nauczanie zintegrowane w klasach niższych. Toruń, Wydawnictwo Adam Marszałek.

Kwaśnica R. (2014), Dyskurs edukacyjny po inwazji rozumu instrumentalnego. O potrzebie refleksyjności. Wrocław, Wydawnictwo DSW.

Ministerstwo Edukacji Narodowej o reformie programowej: I etap edukacyjny: ksztatcenie zintegrowane. Biblioteczka Reformy (1999), Warszawa, MEN.

Muszyńska I., Pańczyk J. (1991), Funkcjonowanie metody ośrodków pracy w szkołach podstawowych dla lekko upośledzonych umystowo. Warszawa, Wydawnictwo WSPS.

Olszewski S. (2016), Pedagog specjalny w świetle metafor - samoopis roli zawodowej. „Niepełnosprawność. Dyskursy Pedagogiki Specjalnej”, 23. 
Pańczyk J. (1981), Podstawowe założenia w pracy pedagogicznej w klasach IV-X. W: K. Kirejczyk (red.), Upośledzenie umysłowe - Pedagogika. Warszawa, PWN.

Parys K. (2005), Refleksje nad przygotowaniem pedagogów specjalnych do pracy zawodowej. W: C. Kosakowski, A. Krause (red.), Normalizacja środowisk życia osób niepetnosprawnych. Olsztyn, Wydawnictwo UWM.

Pasternak E. (1984), Materiaty z metodyki kształcenia upośledzonych umysłowo w stopniu lekkim w szkole specjalnej. Lublin, UMCS.

Piotrowska K. (2016), Nauczycielskie konceptualizacje nauczania na etapie kształcenia zintegrowanego w szkołach specjalnych. Gdańsk, UG (niepublikowana praca magisterska).

Reforma systemu edukacji: projekt (1998), Warszawa, MEN, WSiP.

Reforma oświaty - archiwum. WSiP, SA, http://nauczyciel.wsipnet.pl/serwisy/reforma/arch/ref181a.htm [dostęp: 12.05.2017].

Rura G. (2011), Iluzyjność w ocenie przebiegu reformy programowej przez ministerialnych urzędników. „Problemy Wczesnej Edukacji”, 2.

Sadowska S. (2002), W poszukiwaniu miejsca w edukacji szkolnej dla problematyki niepetnosprawności. W: M. Chodkowska (red), Wielowymiarowość integracji w teorii i praktyce edukacyjnej. Lublin, Wydawnictwo UMCS.

Sadowska S. (2005), Ku edukacji zorientowanej na zmianę społecznego obrazu osób niepetnosprawnych. Toruń, Wyd. Edukacyjne „Akapit”.

Sadowska S. (2006), Drogi (i bezdroża) nauczania matematyki uczniów z niepetnosprawnościa intelektualna w stopniu lekkim. W: Sadowska S. (red.), Nauczanie uczniów z niepetnosprawnościa intelektualna w stopniu lekkim. Wybrane problemy teorii i praktyki. Toruń, Wyd. Edukacyjne „Akapit”.

Sowińska H. (2011), Wstęp. W: H. Sowińska (red.), Dziecko w szkolnej rzeczywistości. Założony a rzeczywisty obraz edukacji elementarnej. Poznań, Wydawnictwo UAM.

Sowińska H. (red.) (2011), Dziecko w szkolnej rzeczywistości. Założony a rzeczywisty obraz edukacji elementarnej. Poznań, Wydawnictwo UAM.

Sowińska H., Krauze-Sikorska H. Kuszak K., Michalak R., Rura G. (2011), Podsumowanie $i$ wnioski. W: Sowińska H. (red.), Dziecko w szkolnej rzeczywistości. Założony a rzeczywisty obraz edukacji elementarnej. Poznań, Wydawnictwo UAM.

Tkaczyk G. (1997), Metodyka nauczania i wychowania początkowego w szkole specjalnej. Lublin, Wydawnictwo UMCS.

Tkaczyk G. (1999), Rewalidacyjne wartości metody ośrodków pracy jako wiodącej w kształceniu specjalnym dzieci upośledzonych umystowo. Lublin, Wydawnictwo UMCS.

Tkaczyk G. (2003), Problemy uczenia się, nauczania, wychowania i rehabilitacji dzieci niepetnosprawnych intelektualnie w kontekście aplikacji metody ośrodków pracy. Lublin, Wydawnictwo UMCS.

\section{Przepisy prawne}

Projekt rozporzadzenia Ministra Edukacji Narodowej zmieniajacego rozporzadzenie w sprawie szczegółowych kwalifikacji wymaganych od nauczycieli oraz określenia szkół i wypadków, w których można zatrudnić nauczycieli niemających wyższego wykształcenia lub ukończonego zakładu kształcenia nauczycieli (http://legislacja.rcl.gov.pl/projekt/12295107) [dostęp 24.06.2017]. 
Rozporzadzenie Ministra Edukacji Narodowej i Sportu z dnia 10 września 2002 r. w sprawie szczegółowych kwalifikacji wymaganych od nauczycieli oraz określenia szkót $i$ wypadków, w których można zatrudnić nauczycieli niemających wyższego wykształcenia lub ukończonego zakładu ksztatcenia nauczycieli (Dz. U. 2002 Nr 155 poz. 1288).

Rozporzadzenie Ministra Edukacji Narodowej i Sportu z dnia 18 stycznia 2005 r. w sprawie warunków organizowania kształcenia, wychowania i opieki dla dzieci i młodzieży niepetnosprawnych oraz niedostosowanych społecznie $w$ przedszkolach, szkołach $i$ oddziałach ogólnodostepnych lub integracyjnych (Dz. U. Nr 19, poz. 167).

Rozporządzenie Ministra Edukacji Narodowej z dnia 12 marca 2009 r. w sprawie szczegółowych kwalifikacji wymaganych od nauczycieli oraz określenia szkót $i$ wypadków, w których można zatrudnić nauczycieli niemajacych wyższego wykształcenia lub ukończonego zakładu ksztatcenia nauczycieli (Dz. U. $2009 \mathrm{nr} 50$ poz. 400).

Rozporzadzenie Ministra Edukacji Narodowej z dnia 14 lutego 2017 r. w sprawie podstawy programowej wychowania przedszkolnego oraz podstawy programowej ksztatcenia ogólnego dla szkoły podstawowej, $w$ tym dla uczniów z niepetnosprawnościa intelektualna $w$ stopniu umiarkowanym lub znacznym, kształcenia ogólnego dla branżowej szkoły I stopnia, ksztatcenia ogólnego dla szkoły specjalnej przysposabiającej do pracy oraz kształcenia ogólnego dla szkoły policealnej (Dz. U. 2017, poz. 356).

Rozporzadzenie Ministra Edukacji Narodowej z dnia 15 lutego 1999 r. w sprawie podstawy programowej kształcenia ogólnego (Dz. U. 1999 Nr 14. poz. 129).

Rozporzadzenie Ministra Edukacji Narodowej z dnia 17 czerwca 2016 r. zmieniajace rozporzadzenie w sprawie podstawy programowej wychowania przedszkolnego oraz kształcenia ogólnego w poszczególnych typach szkót (Dz. U. 2016 poz. 895).

Rozporzadzenie Ministra Edukacji Narodowej z dnia 17 listopada 2010 r. w sprawie warunków organizowania kształcenia, wychowania i opieki dla dzieci i młodzieży niepetnosprawnych oraz niedostosowanych społecznie w przedszkolach, szkołach i oddziałach ogólnodostępnych lub integracyjnych (Dz. U. $2010 \mathrm{Nr} 228$, poz. 1490).

Rozporzadzenie Ministra Edukacji Narodowej z dnia 17 listopada 2010 r. w sprawie warunków organizowania ksztatcenia, wychowania i opieki dla dzieci i młodzieży niepetnosprawnych oraz niedostosowanych społecznie w specjalnych przedszkolach, szkołach i oddziałach oraz w ośrodkach (Dz. U. $2010 \mathrm{Nr} 228$, poz. 1489).

Rozporzadzenie Ministra Edukacji Narodowej z dnia 23 grudnia 2008 r. w sprawie podstawy programowej wychowania przedszkolnego oraz ksztatcenia ogólnego w poszczególnych typach szkót (Dz. U. $2009 \mathrm{Nr}$ 4, poz. 17).

Rozporządzenie Ministra Edukacji Narodowej z dnia 24 lipca 2015 r. w sprawie warunków organizowania kształcenia, wychowania i opieki dla dzieci i młodzieży niepetnosprawnych, niedostosowanych społecznie i zagrożonych niedostosowaniem społecznym (Dz. U. 2015, poz. 1113).

Rozporządzenie Ministra Edukacji Narodowej z dnia 30 maja 2014 r. zmieniajace rozporzadzenie $w$ sprawie podstawy programowej wychowania przedszkolnego oraz kształcenia ogólnego w poszczególnych typach szkót (Dz. U. 2014 poz. 803).

Ustawa z dnia 25 lipca 1998 r. o zmianie ustawy o systemie oświaty (Dz. U. 1998, Nr 117, poz. 759). Ustawa z dnia 7 września 1991 r. o systemie oświaty (Dz. U. $1991 \mathrm{Nr} 95$ poz. 425).

Ustawa z dnia 8 stycznia 1999 r. Przepisy wprowadzające reformę ustroju szkolnego (Dz. U. 1999, $\mathrm{Nr} 12$, poz. 96). 